\title{
Impact of Hepatitis C Virus Infection on Kidney Transplantation
}

\author{
Yasser Soliman \\ Internal Medicine and Nephrology Department, Ain Shams University.
}

\begin{abstract}
Hepatitis $\mathrm{C}$ virus (HCV) infection increases morbimortality in renal transplantation. Hepatitis $\mathrm{C}$ virus positive kidney transplant candidates who remain on the waiting list show a greater risk of mortality than those who are transplanted. The aim of this study was to examine the impact of $\mathrm{HCV}$ infection on patient and allograft survival after kidney transplantation. Eighty two patients with end stage renal disease underwent kidney transplantation were included in this study. The patients were classified into group I including $46 \mathrm{HCV}$ negative patients (HCV-) and group II including $36 \mathrm{HCV}$ antibody and HCV-RNA positive patients $(\mathrm{HCV}+)$. The immunosuppressive protocols were similar in both groups. All recipients were followed up for 3years.Results: There were statistically insignificant differences $(P>0.05)$ between both groups as regard age, gender and donor type (living related or unrelated). Hemodialysis duration before transplantation was highly significant $(\mathrm{P}<0.01)$ longer among $\mathrm{HCV}+$ group ( $4.9 \pm 3.7$ years) compared to $\mathrm{HCV}$ - patients $(2.4 \pm 4.3$ years). One patient died from each group showing insignificant difference $(\mathrm{P}>0.05)$; 2 grafts $(4.3 \%)$ lost in $\mathrm{HCV}$ - group and $3(8.3 \%)$ in $\mathrm{HCV}+$ group with also insignificant difference $(\mathrm{P}>0.05)$. Five recipients $(10.9 \%)$ in group I experienced delayed graft function compared to $2(5.6 \%)$ recipients in group II with statistically insignificant difference. There was a significantly $(\mathrm{P}<0.05)$ more number of acute rejection episodes among $\mathrm{HCV}+$ patients $(11=30.6 \%)$ than $\mathrm{HCV}$ - patients $(5=10.9 \%)$.New onset diabetes mellitus occurred more among HCV+ (19.4\%) than HCV- (8.7\%) recipients, however the difference was insignificant. There was a significant $(\mathrm{P}<0.05)$ higher incidence of cytomegalovirus disease among HCV+ $(11.1 \%)$ than HCV- $(2.2 \%)$ recipients. Conclusion: This study suggested that $\mathrm{HCV}$ positivity does not significantly affect patient and graft survival despite the significant increased incidence of acute rejection episodes and cytomegalovirus disease. Lastly, all measures should be taken to prevent HCV transmission in dialysis population.
\end{abstract}

\section{Introduction}

Since hepatitis C virus (HCV) was identified in 1989 by Choo et al, as a main cause of non-A non -B hepatitis, HCV infection has achieved a great relevance in nephrology on the basis of its high prevalence among dialysis patients, renal allograft recipients as well as in essential mixed cryoglobulinemia with associated membranoproliferative glomerulonephritis $^{(1,2,3)}$. Renal transplantation confers an overall survival benefit in $\mathrm{HCV}+$ hemodialysis patients with similar 5-year patients and graft survival to those without HCV infection ${ }^{(4)}$. Unfortunately, there is no safe treatment for HCV infection after renal transplantation. It has been reported recently that ribavirin monotherapy impr- oved liver enzymes levels, had no effect on HCV viremia, but seems also not to have a beneficial effect on liver fibrosis ${ }^{(5)}$.

\section{Aim Of The Work}

The aim of this study was to evaluate the effect of $\mathrm{HCV}$ infection among end stage renal disease (ESRD) patients after undergoing kidney transplantation.

\section{Patients And Methods}

This prospective study included 82 patients with ESRD. All were receiving their first living kidney transplants at Naser Institute, and Ain Shams University 


\section{Yasser Soliman}

Specialized Hospital. The patients were classified according to HCV status into 2 groups. Group I: included $46 \mathrm{HBs} \mathrm{Ag}$, and $\mathrm{HCV}$ antibody negative (HCV-) patients, $28(60.9 \%)$ males and 18 (39.1\%) females; $31(82.6 \%)$ patients received living related grafts and the rest 14(17.4) were unrelated. Eight patients of group I were preemptive transplantation. Group II: Included $36 \mathrm{HBs}$ $\mathrm{Ag}$ negative $\mathrm{HCV}$ antibody and RNA positive patients, $20(55.6 \%)$ males and 16 $(44.4 \%)$ females, $30(83.3 \%)$ patients received related and 6 (16.7) unrelated grafts.

All patients were exposed to history taking including the etiology of renal failure, duration on hemodialysis, blood transfusion, and antiviral treatment (in group II). All patients underwent blood testing for serum alanine transferase (ALT), aspartate transferase (AST), albumin, prothrombin time, creatinine, blood urea nitrogen (BUN), and blood glucose level. Anti-HCV antibodies were determined with a third generation enzyme linked immunoassay (Abbott-laboratories, Chicago, IL, USA).HCV-RNA was detected by qualitative polymerase chain reaction (PCR) using Amplicor Kits (Roche Diagnostic System, Indianapolis, USA).A liver biopsy was indicated for all HCV-RNA- positive patients, irrespective of transaminases levels. All recipients were having <4 HLA mismatch with their donors, and the immunosuppressive protocols were similar in both groups in the form of triple therapy with steroids, cyclosporine, and azathioprin. The patients were followed up for 3 years as regard renal function tests, liver function tests, occurrence of delayed graft function (DGF)-defined as the transient requirement for dialysis beginning in the first week after the transplant operation ${ }^{(6)}$-, acute rejection, new onset diabetes mellitus (DM), and cytomegalovirus disease.

\section{Statistical Methods}

SPSS statistical software package, v.9.02, Echosoft Corp, USA, 1998 was used for data analyze. Dates were expressed as Mean \pm SD for quantitative measures and both number and percentage for categorized data. Wilcoxon Rank sum test was used for comparison between two independent mean groups for non parametric data. Lastly, Chisquare test was used for correlation between each 2 independent techniques. The probability of error at 0.05 was considered significant, while at 0.01 highly significant.

\section{Results}

Table-1 shows the characteristics of patients in group I (HCV-) and group II $(\mathrm{HCV}+)$. The mean age in group I was $(42.4 \pm 11.2$ years $)$ with non significant difference ( $\mathrm{P}>0.05)$ from group II (44 \pm 10.5 years). Also, there was non significant difference between both groups as regard gender $(\mathrm{P}>0.05)$. Though $30.4 \%$ of patients in group I received kidneys from unrelated donors compared to $16.7 \%$ only in group II, the difference was insignificant $(\mathrm{P}>0.05)$. There was a highly significant $(\mathrm{P}<0.01)$ longer duration of hemodialysis before transplantation in group II than group I (4.9 $\pm 3.7 \& 2.4 \pm 4.3$ years respectively).

Table-2 Shows non significant $(\mathrm{P}>0.05)$ difference between group I and group II as regard serum creatinine level during the follow up period, while a highly significant $(\mathrm{P}<0.001)$ higher level of BUW in group II $(38.2 \pm 11.7 \mathrm{mg} / \mathrm{dl})$ compared to group I ( $21 \pm 13.1 \mathrm{mg} / \mathrm{dl}$ ). One patient died in each group (both from infection) resulting in non significant difference $(\mathrm{P}>0.05)$ in patient survival between the two groups after 3 years, and the relative risk was 1.3 with $\mathrm{HCV}$ positivety. Also, there was insignificant difference $(\mathrm{P}>0.05)$ as regard three years graft survival between HCV $(95.7 \%)$ and $\mathrm{HCV}+(91.7 \%)$ and the relative risk of graft loss is 1.9 with $\mathrm{HCV}$ positively. Five recipients (10.9\%) experienced delayed graft function in group I compared to 11 recipients $(5.6 \%)$ in group II but the difference was insignificant $(\mathrm{P}>0.05)$. There was a significant $(\mathrm{P}<0.05)$ higher incidence of acute rejection episodes (all were steroid sensitive) in group II (30.6\%) than group I (10.9\%) with a relative risk of 2.8 . There was a higher 
incidence of new onset DM in group II $(19.4 \%)$ than group I $(8.7 \%)$, however the difference was insignificant and the relative risk of developing DM with $\mathrm{HCV}$ positively was 2.2.There was a significantly
$(\mathrm{P}<0.05)$ higher incidence of cytomegalovirus disease in $\mathrm{HCV}+$ group II $(11.1 \%)$ in comparison to group I $(2.2 \%)$ with 5.1 relative risk.

Table 1: Patients Demographic Characteristics, and clinical metrics in group I (HCV-) and group II (HCV+).

\begin{tabular}{|c|c|c|c|c|c|c|}
\hline \multicolumn{2}{|c|}{ Parameter } & $\begin{array}{c}\text { Group I } \\
\mathrm{N}=46\end{array}$ & $\begin{array}{c}\text { Group II } \\
\mathrm{N}=36\end{array}$ & $\mathrm{Z}$ & P-Value & Significance \\
\hline \multicolumn{2}{|c|}{ Age (Years) mean \pm SD } & $42.4 \pm 11.2$ & $44 \pm 10.5$ & -0.7 & $>0.05$ & NS \\
\hline \multirow{2}{*}{ Gender } & Male & $28(60.9 \%)$ & $20(55.6 \%)$ & \multirow{2}{*}{0.63} & \multirow{2}{*}{$>0.05$} & \multirow{2}{*}{ NS } \\
\hline & Female & $18(39.1 \%)$ & $16(44.4 \%)$ & & & \\
\hline \multirow{2}{*}{ Donor Type } & LR & $32(69.6 \%)$ & $30(83.3 \%)$ & \multirow{2}{*}{1.44} & \multirow{2}{*}{$>0.05$} & \multirow{2}{*}{ NS } \\
\hline & LUR & $14(30.4 \%)$ & $6(16.7 \%)$ & & & \\
\hline \multicolumn{2}{|c|}{ Hemodialysis Duration (Years) mean $\pm \mathrm{SD}$} & $2.4 \pm 4.3$ & $4.9 \pm 3.7$ & -2.8 & $<0.01$ & HS \\
\hline
\end{tabular}

SD : Standard deviation

LR : Living related.

LUR : Living unrelated
NS : Non significant.

HS : Highly significant.

Table 2: Patients and Graft survival during the follow up period ( 3 years)

\begin{tabular}{|c|c|c|c|c|c|c|}
\hline Parameter & $\begin{array}{l}\text { Group I } \\
\mathrm{N}=46\end{array}$ & $\begin{array}{c}\text { Group II } \\
\mathrm{N}=36\end{array}$ & $\mathrm{Z}$ & P-Value & Significance & RR \\
\hline BUN (mgldl) mean \pm SD & $21 \pm 13.1$ & $38.2 \pm 11.7$ & -6.2 & $<0.001$ & HS & \\
\hline S. Creatinine (mgldl) mean \pm SD & $1.7 \pm 1.1$ & $1.8 \pm 1.4$ & -0.4 & $>0.05$ & NS & \\
\hline Death $\quad \mathrm{n}(\%)$ & $1(2.2 \%)$ & $1(2.8 \%)$ & -0.2 & $>0.05$ & NS & 1.3 \\
\hline Graft Failure & $2(4.3 \%)$ & $3(8.3 \%)$ & -0.8 & $>0.05$ & NS & 1.9 \\
\hline Delayed Graft Function & $5(10.9 \%)$ & $2(5.6 \%)$ & 0.85 & $>0.05$ & NS & 2 \\
\hline Acute Rejection & $5(10.9 \%)$ & $11(30.6 \%)$ & -2.2 & $<0.05$ & $\mathrm{~S}$ & 2.8 \\
\hline Diabetes Mellitus & $4(8.7 \%)$ & $7(19.4 \%)$ & -1.4 & $>0.05$ & NS & 2.2 \\
\hline Cytomegalovirus Disease n (\%) & $1(2.2 \%)$ & $4(11.1 \%)$ & -1.7 & $<0.05$ & $\mathrm{~S}$ & 5.1 \\
\hline
\end{tabular}

SD : Standard deviation

$\mathrm{RR}$ : Relative risk
HS : Highly significant

NS : Non significant

\section{Discussion}

This study showed no significant difference between both groups as regard age, gender, and donor type. There was a significant longer duration of hemodialysis before transplantation in group II $(\mathrm{HCV}+)$ implicating hemodialysis in the prevalence of $\mathrm{HCV}$ among ESRD patients. A similar finding was reported by Bruchfeld et $\mathrm{al}^{(7)}$. 


\section{Yasser Soliman}

The present study showed a slightly increased incidence of patient mortality and graft loss in $\mathrm{HCV}+$ group compared to $\mathrm{HCV}$ - group during the 3 years follow up period, however the differences were insignificant. Pereira study showed that graft and patient survival were not significantly different after 3.5 years between $\mathrm{HCV}+$ and $\mathrm{HCV}-$ kidney transplant recipients ${ }^{(8)}$. Also, Lee et al, reported that graft looses and death rates were not significantly different between $\mathrm{HCV}+$ and $\mathrm{HCV}$ - kidney recipients ${ }^{(9)}$. In contrast, Legendre et al, Gentil et al, and Bruchfeld et al, observed a significantly higher percentage of graft loss among $\mathrm{HCV}+$ than HCV- renal recipients ${ }^{(10,11,7)}$. Batty et al, claimed a $13 \%$ mortality rate in $\mathrm{HSV}+$ and $8.5 \%$ in HCV- patients ${ }^{(12)}$. Nevertheless, Bezard-Behbahani et al, evaluated the impact of $\mathrm{HCV}$ infection occurring after kidney transplantation, and they suggested that HCV infection (in a previously $\mathrm{HCV}$ - recipient before transplantation) did not cause or contribute to renal dysfunction during the one year follow-up period of the study ${ }^{(13)}$. The frequency of new onset DM was significantly higher in $\mathrm{HCV}+(19.4 \%)$ than HCV$(8.7 \%)$ patients. A similar finding was observed by Stehman - Breen et al, resulting in $18 \%$ prevalence of $\mathrm{DM}$ in an $\mathrm{HCV}$ infection cohort ${ }^{(14)}$. There was unexplained statistically insignificant higher incidence of delayed graft function among HCV- than $\mathrm{HCV}+$ group. On the other hand, there was a significant $(\mathrm{P}<0.05)$ increased number of acute rejection episodes among $\mathrm{HCV}+$ $(11=30.6 \%)$ compared to HCV- $(5=10.9 \%)$ recipients. This study showed a significantly increased incidence of cytomegalovirus disease in group II (11.1\%) with a RR 5.1 in comparison to HCV- group. Till publishing this work, there were no trials in the literature correlating $\mathrm{HCV}$ status and cytomegalovirus disease after kidney transplantation.

\section{Conclusion\& Recommendations}

This study suggested that HCV infection among ESRD patients does not affect significantly patient and renal allograft survival after kidney transplantation despite the significant increased incidence of acute rejection episodes and cytomegalovirus disease during the first 3 years following transplantation. A more extended study is advisable to identify the impact of $\mathrm{HCV}$ infection on the long term patient and graft survival. Lastly, all measures should be taken to prevent $\mathrm{HCV}$ transmission in dialysis population.

\section{Refrences}

1. Choo QL, kuo G, weiner AJ, Oberby LR, Bradley DW, Houghto M: Isolation of cDNA clone derived from blood bone none-A, none-B hepatitis genome. Science 1989;244:359-362.

2. Druwe PM,Michielsen PP, Ramon AM, De Broe ME :Hepatitis C and nephrology.Nephro Dial Transplant 1994; 9:230237

3. Roth D: Hepatitis C virus: The nephrologist's view.Am J Kidney Dis 1995; 25: 3-16.

4. Gane E, and Pilmore H: Management of chronic viral hepatitis before and after renal transplantation. Transplantation 2002; 74: 427-437.

5. Kamar N, Sandres- Saune K, Selves J, Ribes D, Cointsault O, Durand D, Isopet J, Rostaing L: Long term ribavirin therapy in hepatitis $C$ virus-positive renal transplant patient - effects on renal function and liver histology. Am J Kidney Dis 2003; 42:184192.

6. Forman JP, Nina Tolkoff-Rubin, Manuel Pascula, Julie Lin. Hepatits C,Acute humoral Rejection, and Renal Allograft survival . J Am Soc Nephrol 2004; 15:3249-3255.

7. Bruchfeld A, Wilczek H, Elinder CG: Hepatitis $\mathrm{C}$ virus infection, time in renal replacement therapy, and outcome after kidney transplantation. Transplantation, 2004; 78:745

8. Pereira BJ: Effects of hepatitis C infection and renal transplantation on survival in end stage renal disease. The New England Organ Bank Hepatitis C Study Group. Kidney Int 1998; 53:1374.

9. Lee WC, Shu KH, Cheng $\mathbf{C H}$, et al., : Long-term impact of hepatitis B, C virus infection on renal transplantation. . 2001; Am J Nephrol 21:300. 
10. Legendre $\mathbf{C H}$, Garrigue V, Le Bihan $\mathbf{C}$, et al: Harmful Long-term impact of hepatitis $\mathrm{C}$ virus infection in kidney transplant recipients. Transplantation 1998; 65: 667.

11. Gentil MA, Rocha JL, Algarra GR, et al: Impaired kidney transplant survival in patients with antibodies to hepatitis $\mathrm{C}$ virus. Nephrol Dial Transplant 1999;14:2455

12. Batty DS Jr, Swanson Sj, Kirk AD, et al: HCV seropositivity at the time of renal transplantation in the US: associated factors and patient survival. Am J transplant, 2003; 3:1453

13. Behzard-Behbahani A,Mojiri A, Tabei SZ, Farhadi-Andarabi A, et al: Outcome of hepatitis $B$ and $C$ virus infection on graft function after renal transplantation. Transplant Proc. 2005; 37(7):3045-7

14. Stehman-Breen CO, Emerson S, Gretch D, et al: Rise of death among chronic dialysis patients infected with hepatitis C virus. Am J Kidney Dis, 1998; 32:629. 


\section{اثز عدوى فيروس الالتهاب الكبدى (سى) على زراعة الكلى ياسر سليمان \\ قسم الباطنة ـ كلية الطب - جامعة عين شمس}

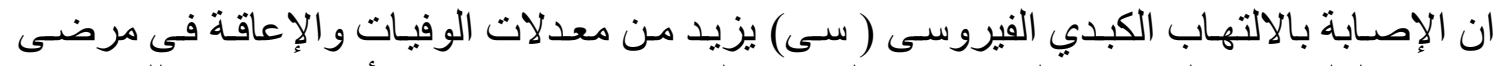

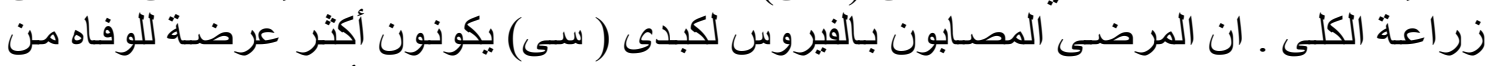

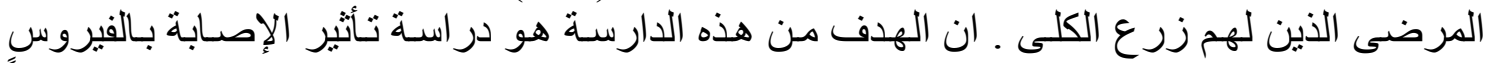

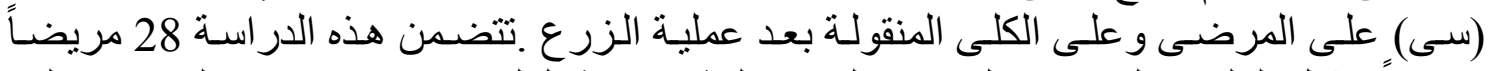

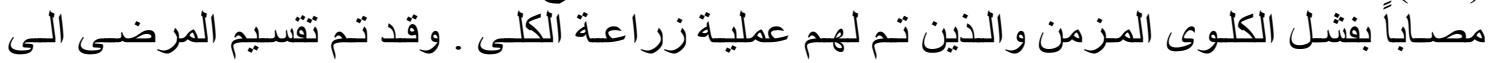

المجموعة الاولى :- نتضمن 46 مريضاً غير مصابين بالفيروس الكبدي (سى) المجموعتين :- المجموعة الاوعة الثماني

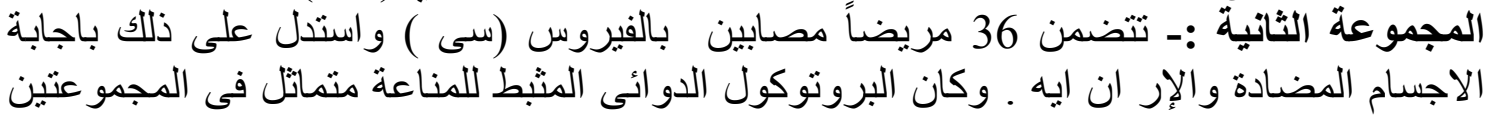

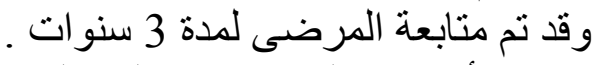

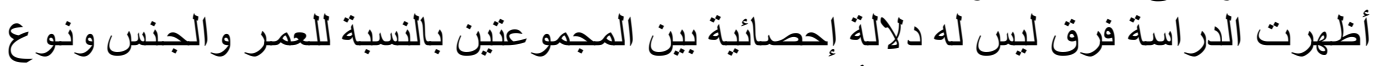

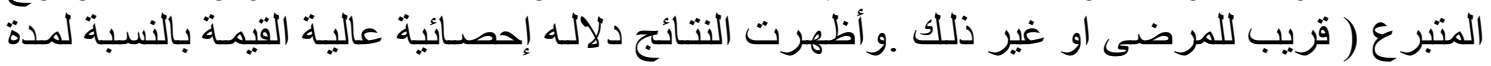

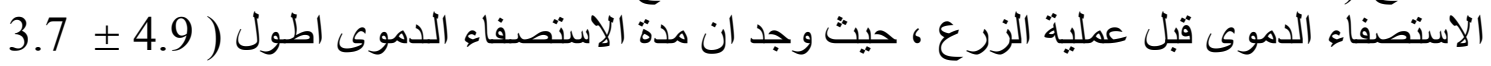

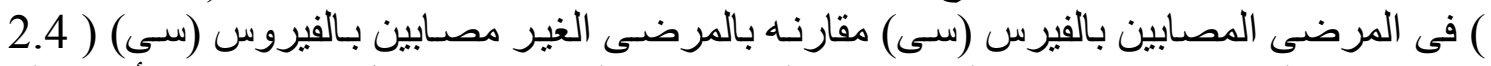

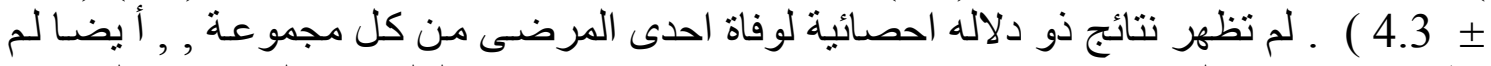

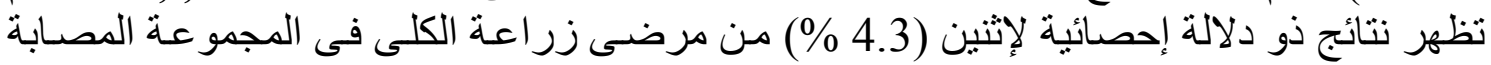

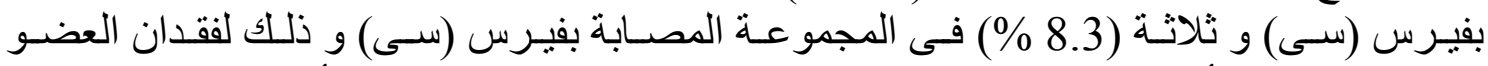

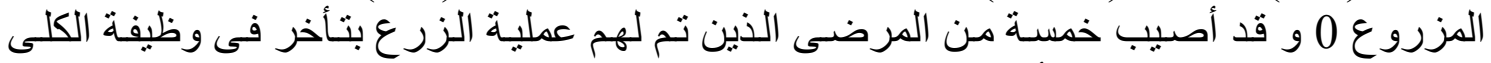

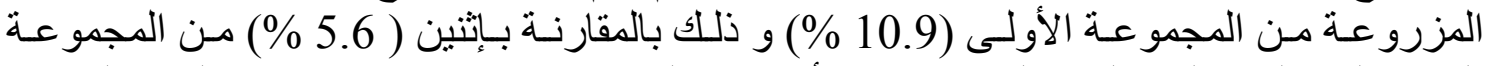

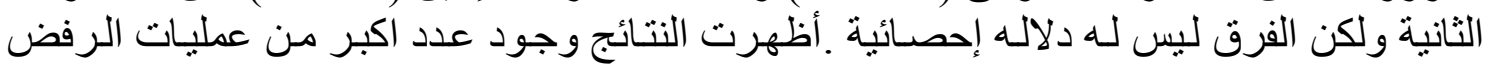

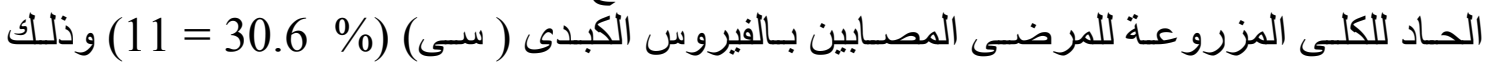

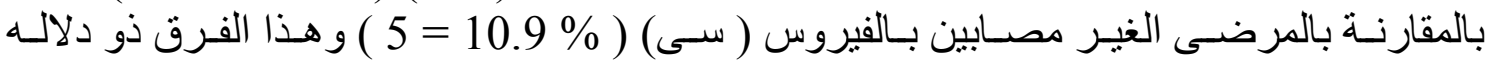

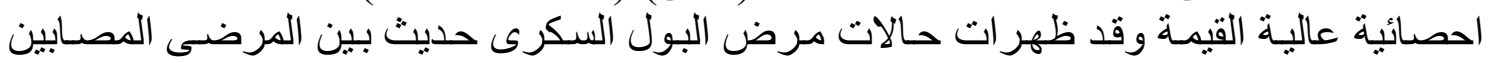

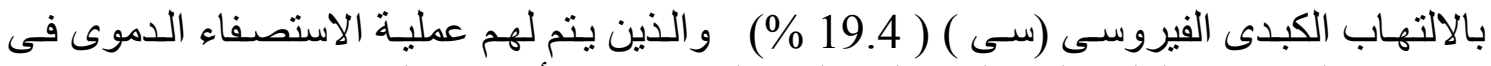

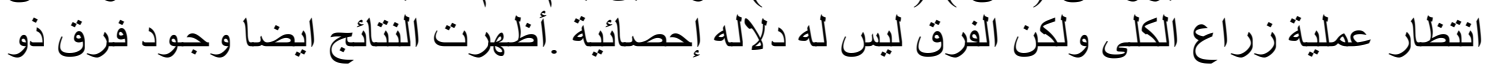

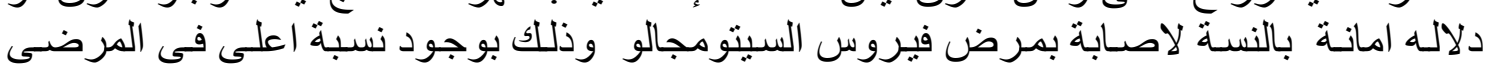

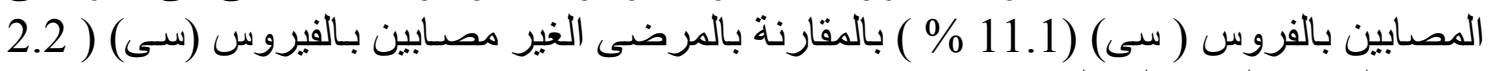

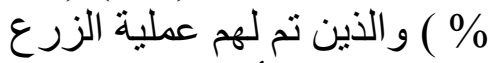

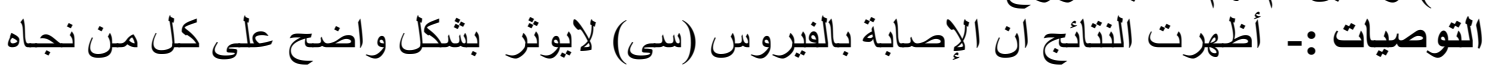

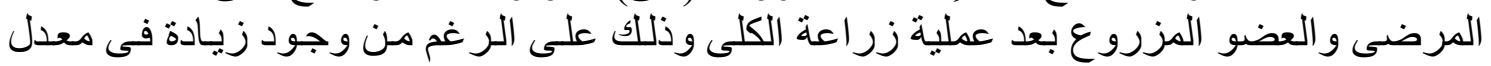

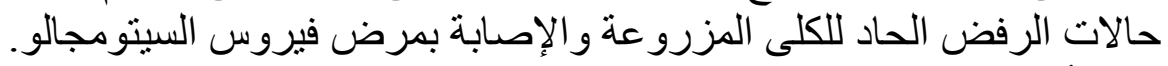

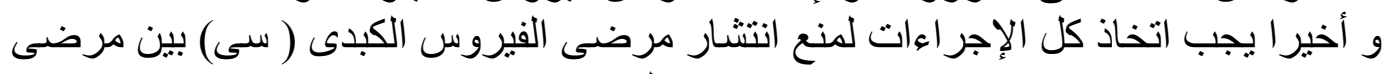

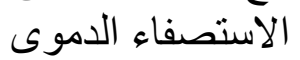

